\title{
マイコン利用心電図シミュレータとそれによる 自動診断システムの評価
}

\section{○藤田 忠和* 広門 一孝* 柳 茂夫** 田中館明博**}

\section{1.はじめに}

われわれは，心電図自動診断システムの総合的な性能 を評価するためにマイクロプロセッサーを利用した心電 図シミュレータを製作した。昨年のこの大会ではこの 装置を使って当センターで使用している Telemed 社 EPIC システムを対象とした評価実験成績について紹介 したが，今回は更にそれを進めて国内で現在利用されて いる 6 種類のシステムについて性能比較を試 みたとこ ろ，2，3の知見を得たので報告する。

\section{2. 方 法}

6 種類のシステム $(\mathrm{A} \sim \mathrm{F})$ は各々処理型式, 伝送路 等の設置環境が異なり， $\mathrm{A}$ 扎よび $\mathrm{B}$ システムについては 特に Cart 間のばらつきと信号伝送路の違いによる差を 調べるため $2 \sim 3$ 台の Cart を使用した。そして主に波 形計測の再現性と各システム間の計測值の差を細かく調 ベる目的に健常者擬似信号を使用した。この波形を使っ てシミュレータのプログラム上で R-R 間隔を一定の心 拍ごとに変化させることで, SVPC 様の不整脈を発生す ることができる。また各システムの不整脈診断あるいは 異常診断に対する大まかな再現性をとらえるため SVPC 様波形と WPW 波形を合わせて使用した。比較実験に は以上 3 種類の擬似信号を各システム，各 Cart につい て各々連続10〜20回入力し得られた波形計測值と診断結 果について比較検討した。

\section{3. 結 果}

健常者擬似信号を使用した $\mathrm{A}$ システム 3 施設間での結果 については, $\mathrm{V}_{5}$ の $\mathrm{R}$ に $0.1 \mathrm{mV}$ の偏りが認められたが 通常の心電図検査で慣用されている精度に比べて非常に 小さく, このシステムが設置されている場所や信号伝送 路に対して計測精度が左右されないことを示している。 同一の信号を使用した実験結果を各システム間で比較す

\footnotetext{
Microcomputerized ECG simulater and evaluation of computerized ECG system by it, -Report 2-

*（財）北里ヘルス・サイェンス・センター $* *$ 北里大学医学部
}

ると QT interval と QRS Axes に大きな偏りがあるこ とが示され，各システムが波形計測において異なった方 式を採用していることが伺える。計測値の再現性をみる

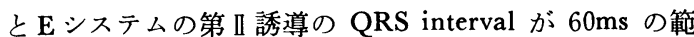
囲にわたっていたものの，診断結果は10回の trial で全 て Normal ECG であった。R-R 間隔を SVPC 様に変 化させた擬似信号での実験では $\mathrm{A}, \mathrm{B}, \mathrm{C}$ および $\mathrm{F}$ システ ムは SVPC をよくとらえ, その再現性もよかった。しか し C システムは同時に sinus arrhythmia の診断を与え ている。Dシステムでは特に不整脈診断のための誘導を 第 II か $V_{1}$ に選択できるのであるが，第 II 誘導を選択し た場合 10 回中 5 回は心房細動と診断したが $V_{1}$ の誘導を 選択した場合10回中 9 回はSVPC をとらえ診断の再現 性が向上された。Eシステムでは10回中 6 回 SVPC or VPC と診断し残り 4 回は second degree A-V Block と 診断した。WPW 波形を用いた実験については，A シス テムは伝送路に関係なくWPW と診断する率は高くそ の再現性もよかった。Bシステムでもその感度は高かっ たが20回中10回は SVPC の診断がついた。D システム では第 II 誘導を選択した場合 1 回だけ WPW と診断し その他は様々な診断がつけられた。このような傾向は $\mathrm{V}_{1}$ 誘導を用いた場合も同様であった。 $\mathrm{E}$ システムでは 10 回中 5 回 WPW と診断し, $\mathrm{F}$ システムでは 1 回も WPW の診断がつかなかった。

\section{4. まとめ}

最近各社のシステムの性能はハード，ソフトの両面と も増々向上し，各システムの特徵を患者心電図データに よる診断実験から適切に表現することは難しくなってき ている。今回は 3 種類のシミュレータ心電図波形を用い た実験について特に計測値，診断結果の再現性を中心に 報告したが，今後この波形ライブラリーをさらに払張し ていけば各社のシステムについて端末や伝送路のハード 面の性能も含めた計測診断プログラムの診断性能をわれ われユーザーの立場から公平に評価できるものと考えら れる。 